\title{
PERANCANGAN GAME EDUKASI TEBAK GAMBAR BERBASIS ANDROID UNTUK ANAK-ANAK USIA TK
}

\author{
Albert V. Dian Sano ${ }^{1}$, Mega Intanadias Calista ${ }^{2}$ \\ ${ }^{1}$ School of Information Systems Bina Nusantara, Jakarta Indonesia \\ albert_vds@yahoo.com \\ ${ }^{2}$ Computer Science, Institut Teknologi Kreatif, Malang Indonesia \\ egaadias@gmail.com
}

\begin{abstract}
ABSTRAK
Tujuan dari kajian ini adalah merancang game tebak gambar yang memiliki sisi edukasi dan berbasis smartphone android untuk anak - anak usia TK. Adapun manfaat game yang dihasilkan dari kajian ini adalah: 1) sebagai media pembelajaran yang menyenangkan bagi anak - anak usia TK, 2) dapat menumbuhkan minat belajar anak - anak usia TK, 3) serta dapat meningkatkan kemampuan memahami bentuk hewan, benda, dan buah bagi anak usia prasekolah. Game edukasi ini dirancang untuk anak - anak usia TK (4-7), ditargetkan pada smartphone dengan sistem operasi android. Rancangan game edukasi tebak gambar ini dibagi menjadi dua kategori, 1) menebak nama hewan dan 2) menebak nama benda. Setiap kategori terdiri dari tiga level yaitu, 1) easy, 2) normal, dan 3) hard.
\end{abstract}

Kata Kunci: Game Edukasi, Rancangan Game, Smartphone Android

\begin{abstract}
The purpose of this study is to design a picture guess game that has an educational side. The benefits of games resulting from this study are: 1) as a fun-learning media for kindergarten children, 2) to foster learning process for kindergarten children, 3) and can improve the ability to understand the shape of animals, objects, and fruits for the children. This educational game is designed for kindergarten children (age of 4-7 year old), targeted at smartphones with android operating system. The design of this educational game is divided into two categories, 1) guess the names of animals and 2) guess the names of objects. Each category consists of three levels: 1) easy, 2) normal, and 3) hard.
\end{abstract}

Keywords: Educational Game, Game Design, Android Smartphone 


\section{Pendahuluan}

Teknologi semakin hari semakin berkembang, teknologi tidak hanya di gunakan untuk memudahkan pekerjaan manusia namun juga sebagai media penghibur, banyak produk - produk teknologi Multimedia yang digunakan sebagai media penghibur, contohnya adalah : Film, Video Game, dsb. Teknologi yang sangat berkembang saat ini ialah Smarthphone. Banyak kemudahan yang dapat kita dapat dengan menggunakan smartphone, mulai dari berkomunikasi, bermain game, mencari informasi, dan sebagainya. Dikutip dari website kominfo, jumlah pengguna smarthphone di Indonesia pada tahun 2018 lebih dari 100 juta pengguna. Pengguna smartphone saat ini tidak hanya orang dewasa saja, melainkan juga anak - anak, jumlah anak - anak yang menggunakan gadget meningkat hampir dua kali lipat (dari 38 persen menjari 72 persen) (Yusmi Warisyah, 2015).

Smartphone membawa dampak positif dan negatif pada penggunanya, Dampak positif yang didapat dari perkembangan smarthphone salah satunya adalah memudahkan pengguna mendapatkan informasi. Dampak negatif penggunaan smarthphone adalah pengguna smarthphone tak terkecuali anak - anak kecanduan untuk menggunakan smarthphone. Anak-anak yang sering menggunakan gadget, seringkali lupa dengan lingkungan sekitarnya (Yusmi Warisyah, 2015), sehingga mereka enggan untuk pergi keluar rumah dan membuat interaksi sosial mereka berkurang.

Bermain merupakan suatu kebutuhan bagi anak anak, bermain merupakan sebuah stimulus untuk perkembangan anak. Bermain pada anak dapat meningkatkan perkembangan sesnsor motorik, perkembangan kognitif, sosialisasi, kreativitas, dan perkembangan pada anak lainnya. Bermain dan anak merupakan satu kesatuan yang tidak dapat dipisahkan. Aktivitas bermain dilakukan anak dan aktivitas anak selalu menunjukkan kegiatan bermain(Martha Christianti, 2007).

Jenis permainan saat ini sangat bermacam macam, mulai dari permainan olahraga, permainan tradisional, hingga permainan digital yang dapat kita temui pada smartphone atau biasanya disebut Game Mobile. Di era digital ini minat anak - anak pada game mobile, hal tersebut dapat kita ketahui dari jumlah data yang telah saya sebutkan diatas bahwa jumlah anak - anak yang menggunakan gadget meningkat hampir dua kali lipat (dari 38 persen menjari 72 persen) (Yusmi Warisyah, 2015). Game saat ini tidak hanya sebatas sarana hiburan semata, tetapi telah berkembang menjadi salah satu media edukasi yang memiliki pola pembelajaran untuk menyelesaikan suatu permasalahan agar dapat meningkatkan perkembangan otak seseorang (Agung, Eka, Reni, 2014). Latar belakang tersebut membuat penulis tertarik untuk membuat sebuah Karya Ilmiah yang berjudul "Game Edukasi Tebak Gambar Antena (ayo tebak nama) untuk anak usia sekolah TK".

\section{Landasan Teori}

Landasan teori pada penelitian ini meliputi (1) Smarthphone Sebagai Teknologi Yang Berkembang Saat Ini, (2) Dampak Negatif dan Positif Penggunaan Smarthphone, (3) Pengertian Game, (4) Game Edukasi Untuk Anak - Anak.

\subsection{Smartphone Sebagai Teknologi Yang Berkembang Saat Ini}

Smartphone adalah teknologi yang sangat berkembang saat ini, banyak hal yang bisa kita lakukan menggunakan smartphone diantaranya adalah, mengakses informasi dengan cepat, berkomunikasi jarak jauh, bermain game, bahkan saat ini smartphone dapat kita gunakan untuk mencari nafkah. Dikutip dari website kominfo, jumlah pengguna smarthphone di Indonesia pada tahun 2018 lebih dari 100 juta pengguna. Pengguna smartphone saat ini tidak hanya orang dewasa saja, melainkan juga anak - anak, jumlah anak - anak yang menggunakan gadget meningkat hampir dua kali lipat (dari 38 persen menjari 72 persen) (Yusmi Warisyah, 2015). Hal tersebut menujukkan bahwa smarthphone saat ini merupakan teknologi yang sangat berkembang dan banyak digunakan.

\subsection{Dampak Negatif dan Positif Penggunaan Smarthphone}

Smartphone membawa dampak positif dan negatif pada penggunanya, Dampak positif yang didapat dari perkembangan smarthphone adalah memudahkan pengguna mendapatkan informasi dengan cepat, dapat berkomunikasi jarak jauh, memudahkan mencari tempat dan tujuan dengan adanya fitur GPS saat ini. Banyaknya dampak positif yang bisa didapat oleh pengguna Smartphone membuat banyaknya pengguna smartphone semakin meningkat.

Selain dampak positif smartphone juga membawa dampak negatif bagi penggunanya. Dampak negatif penggunaan smarthphone adalah pengguna smarthphone tak terkecuali anak - anak kecanduan untuk menggunakan smarthphone. Anak-anak yang sering menggunakan gadget, seringkali lupa dengan lingkungan sekitarnya (Yusmi Warisyah, 2015), sehingga mereka enggan untuk pergi keluar rumah dan membuat interaksi sosial mereka berkurang, bahkan kewajiban mereka untuk belajar sering diabaikan karena mereka lebih senang menggunakan smartphone. 


\subsection{Pengertian Game}

Game adalah permainan yang dirancang dengan multimedia yang dapat diakses menggunakan media elektronik seperti komputer atau smartphone. Game (permainan) secara umum adalah sebuah aktivitas rekreasi dengan tujuan bersenang-senang, mengisi waktu luang, atau berolahraga ringan. Permainan biasanya dilakukan sendiri atau bersama-sama (Retno, Moh Husnul, 2013).

\subsection{Game Edukasi Untuk Anak - Anak}

Game edukasi adalah game yang digunakan sebagai alat pendidikan, digunakan sebagai media pembelajaran anak - anak. Game edukasi biasanya digunakan untuk belajar mengenal warna, mengenal huruf dan angka, matematika, sampai belajar bahasa asing. Desainer game edukasi harus benar - benar memperhitungkan bahwa game yang dirancang harus mendidik dan menyenangkan bagi pemainnya.

Game edukasi biasa kita jumpai di toko - toko buku, atau tempat bermain anak namun saat ini kita bisa menjupai game edukasi di playstore dan dapat kita mainkan menggunakan smartphone, banyak sekali game edukasi yang tersedia di playstore.

\subsection{Desain UI, Konten, dan Level}

\subsubsection{Desain UI}

Berikut adalah tampilan animasi opening dari game edukasi tebak gambar.

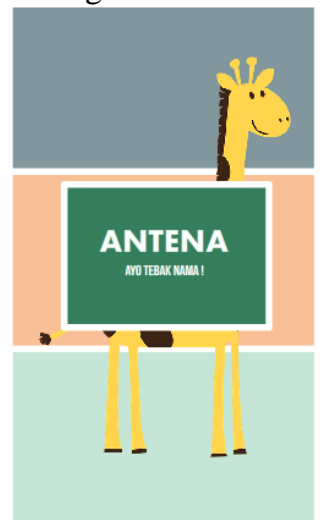

Gambar 1. Tampilan Awal Game

\subsubsection{Kategori}

Berikut adalah tampilan kategori game edukasi tebak gambar, terdapat 2 kategori yaitu kategori pertama adalah tebak hewan, kategori yang kedua adalah tebak benda

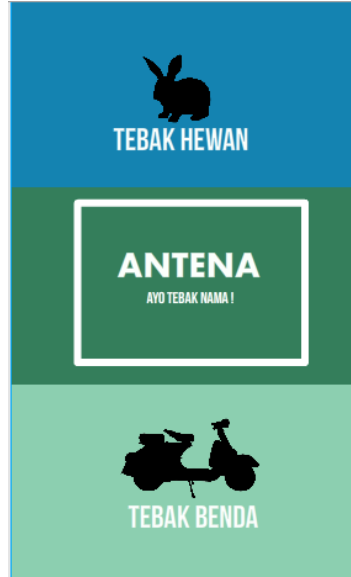

Gambar 2. Tampilan Pilihan Kategori

\subsubsection{Level}

Setiap kategori memiliki 3 tingkatan Level yaitu easy, normal, dan Hard. Pada level easy terdapat 5 soal, pada level normal terdapat 10 soal, pada level hard terdapat 15 soal.

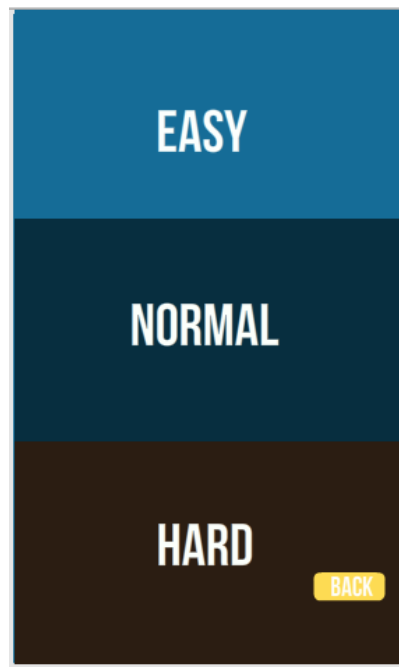

Gambar 3. Tampilan Tingkatan Level Kategori Tebak Hewan

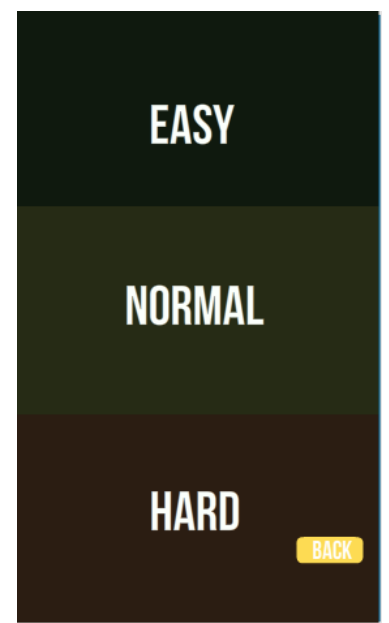

Gambar 4. Tampilan Tingkatan Level Kategori Tebak Benda 


\subsubsection{Kategori Tebak Gambar Hewan}

Berikut adalah salah satu contoh dari game tebak hewan pada level easy, pemain harus memindahkan kotak yang berisi huruf ke dalam kotak kosong, kemudian mengklik tombol cek untuk mengetahui jawaban tersebut benar atau salah.

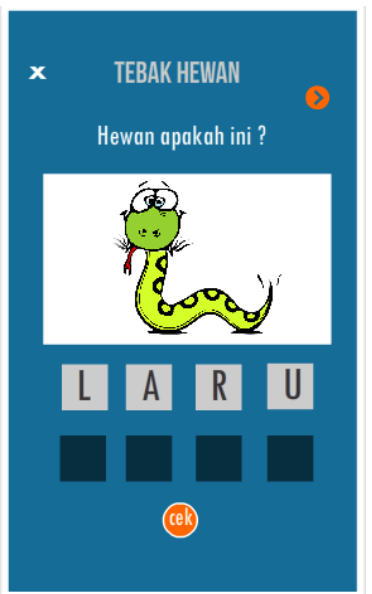

Gambar 5. Tampilan Tebak Gambar Hewan

\subsubsection{Kategori Tebak Gambar Benda}

Berikut adalah salah satu contoh dari game tebak benda pada level easy, pemain harus memindahkan kotak yang berisi huruf ke dalam kotak kosong, kemudian mengklik tombol cek untuk mengetahui jawaban tersebut benar atau salah.

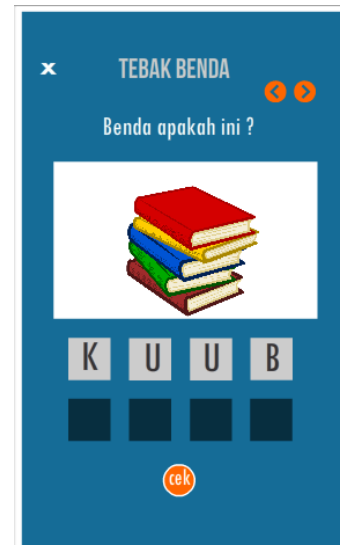

Gambar 6. Tampilan Tingkatan Level Kategori Tebak Benda

\subsubsection{Tampilan Jika Pengurutan Nama}

\section{Benar}

Jika pengurutan huruf benar, maka saat diklik cek akan muncul animasi yang menujukkan bahwa jawaban kita benar.

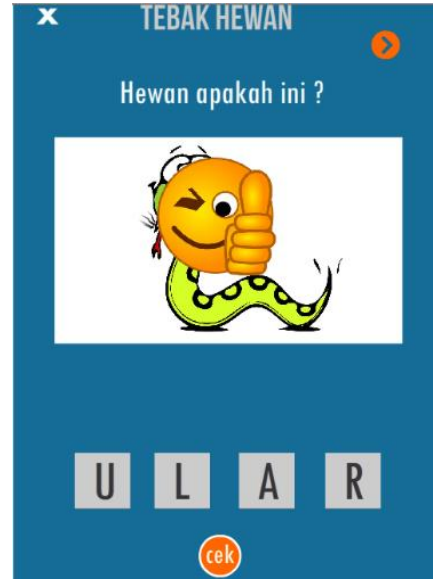

Gambar 7. Tampilan Jika Jawaban Benar

\subsubsection{Tampilan Jika Pengurutan Nama \\ Salah}

Jika pengurutan huruf benar, maka saat diklik cek akan muncul animasi yang menujukkan bahwa jawaban kita salah.

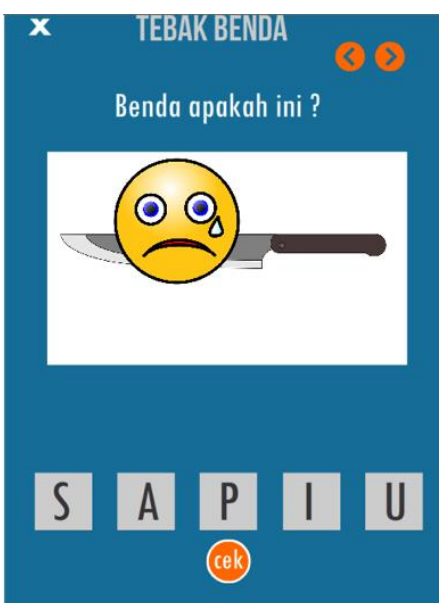

Gambar 8. Tampilan Jika Jawaban Salah

\subsection{Pembahasan}

Aplikasi game edukasi Tebak gambar ini dibuat pada software Adobe Flash CS 3 dengan menggunakan Action Script 2.0. Game edukasi Tebak gambar ini diberi nama "Antena (Ayo Tebak Nama)", nantinya aplikasi game tebak gambar ini dapat dijalankan di smarthphone Android dan juga digunakan sebagai media belajar mengenal benda dan hewan untuk anak - anak usia sekolah TK.

Game edukasi Tebak gambar ini memiliki dua kategori yaitu hewan dan benda, masing - masing kategori memiliki 3 tingkatan level yaitu easy, normal, dan hard. Level easy terdapat 5 soal, level normal terdapat 10 soal, dan level hard terdapat 15 soal. Game edukasi tebak gambar ini dilakukan dengan cara pengurutan huruf, cara pengurutan huruf adalah melakukan drag dari kotak yang berisi huruf kedalam kotak kosong berwarna abu - abu. 


\section{Penutup}

\subsection{Kesimpulan}

Perancangan Game edukasi tebak gambar untuk anak usia TK adalah sebagai bentuk menciptakan sebuah pembelajaran yang menyenangkan namun tetap memiliki sisi edukatif. Di era digital ini, game edukasi tebak gambar memanfaatkan teknologi android diharapkan mampu mendukung kegiatan belajar anak - anak usia TK dan mampu meningkatkan minat belajar mereka.

\subsection{Saran}

Pada aplikasi game edukasi tebak gambar untuk anak usia TK ini masih memiliki banyak kekurangan. Dalam upaya pengembangan aplikasi ini, berikut terdapat beberapa saran yang ditemukan

1. Diharapkan pada pengembangan selanjutnya, game ini bisa memiliki sistem pemberian poin jika jawaban benar.

2. Diharapkan juga game ini nantinya memiliki peningkatan gambar dan animasi yang lebih menarik lagi.

\section{Daftar Pustaka}

Cristianti Martha, 2007. Anak dan Bermain, Yogyakarta : Universitas Negeri Yogyakarta

Kominfo.(2015, 2 Oktober). Indonesia Raksasa Teknologi Digital Asia, Diperoleh 25 Juni 2018, dari https://www.kominfo.go.id/conte nt/detail/6095/indonesia-raksasateknologi-digitalasia/0/sorotan_media

Pamungkas Agung., Widiyanto Puji E., Angreni Renni , 2014. Penerapan Algoritma A* (A Star) Pada Game Edukasi The Maze Island Berbasis Android, Palembang : STMIK GI MDP

Wardhani Retno, danYaqin Husnul M. 2013. Game Dasar-Dasar Hukum Islam Dalam Kitab Mabadi'ul Fiqh Jilid I, Lamongan : Universitas Islam Lamongan
Warisyah Yusmi, 2015. PENTINGNYA "PENDAMPINGAN DIALOGIS", ORANG TUA DALAM PENGGUNAAN GADGET PADA ANAK USIA DINI, Ponorogo : FKIP Universitas Muhammadiyah Ponorogo 